\title{
Qual o Seu Diagnóstico?
}

\section{Ulceração Genital Aguda em Jovem}

Margarida Rato', Ana Sofia Borges², Ana Rodrigues², Cândida Fernandes²

'Serviço de Dermatologia do Hospital de Santarém, Santarém, Portugal

${ }^{2}$ Serviço de Dermatologia do Hospital de Santo António dos Capuchos, Centro Hospitalar de Lisboa Central, Lisboa, Portugal

PALAVRAS-CHAVE - Doenças dos Genitais Femininos; Doenças Vulvares; Úlcera.

\section{Dermatology Quiz}

\section{Acute Genital Ulcer in a Young Girl}

KEYWORDS - Genital Diseases, Female; Ulcer/diagnosis; Vulvar Diseases.

\section{CASE REPORT}

A 56-year-old man, phototype VI, from Cape Verde, residenA 17-year-old previously healthy girl, presented with a sudden onset of extremely painful genital ulcers, causing difficulty in walking, preceded by four days of fever and asthenia. Patient reported the last sexual contact 3 months ago. She denied personal history of recurrent oral or genital aphtous lesions. Physical examination revealed vulvar edema and, on both labia minora, two ulcerated lesions, the largest one on the right side with approximately $30 \mathrm{~mm}$, with well demarcated irregular margins and abundant fibrinous exudate in the base (Fig. 1). Inguinal lymph nodes were not palpable. Analytically there was leukocytosis $\left(16.7 \times 10^{9} / \mathrm{L}\right)$ with $80.1 \%$ neutrophils and an elevated C-reactive protein $(71.5 \mathrm{mg} / \mathrm{L})$. PCR testing for herpes simplex virus 1 and 2 on the ulcer exudate was negative. Treponema pallidum and HIV serologies were negative. There was evidence of prior cytomegalovirus and Epstein-Barr virus infections (lgG positive, lgM negative). Culture of the ulcer exudate was negative. The patient was treated with naproxen (250 mg twice daily) with clinical improvement (Fig. 2) and complete resolution of the lesions within 2 weeks. No recurrences occurred during a 6 months period of follow-up.

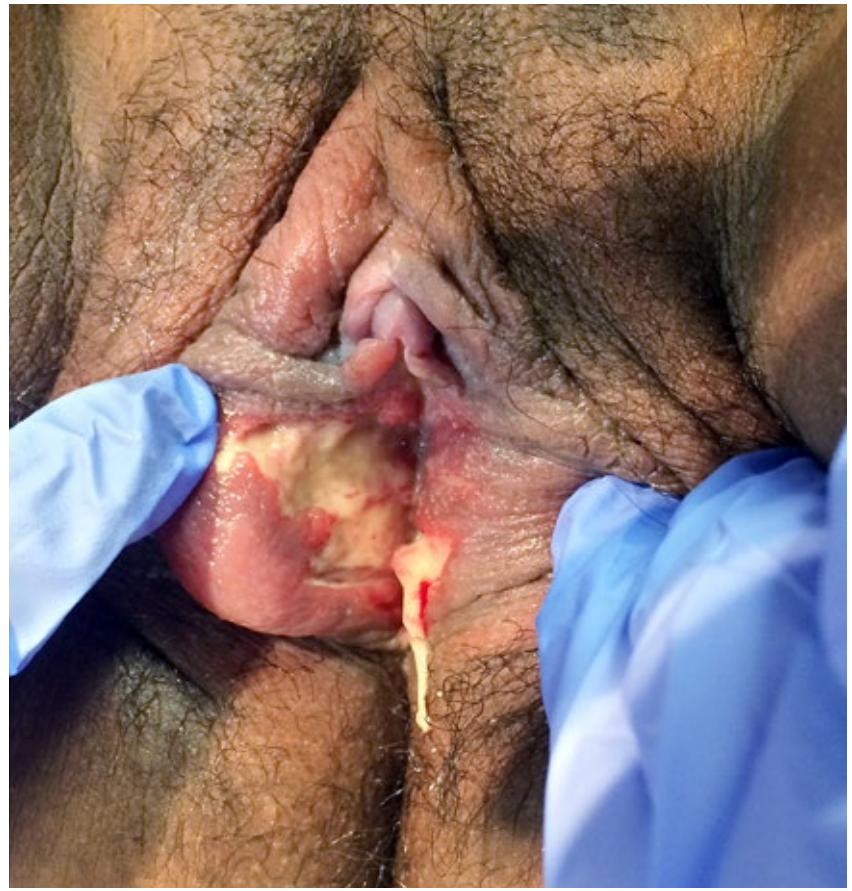

Figure 1 - Bilateral ulcers located in labia minora, covered by an abundant fibrinous exudate.
Correspondência: Margarida Rato

Serviço de Dermatologia - Hospital de Santarém EPE

Avenida Bernardo Santareno

2005-177 Santarém, Portugal

E-mail: margaridagaiorato@gmail.com

DOI: https://dx.doi.org/10.29021/spdv.77.1.976
Recebido/Received

24 Julho/July 2018

Aceite/Accepted

24 Setembro/September 2018 


\section{Qual o Seu Diagnóstico?}

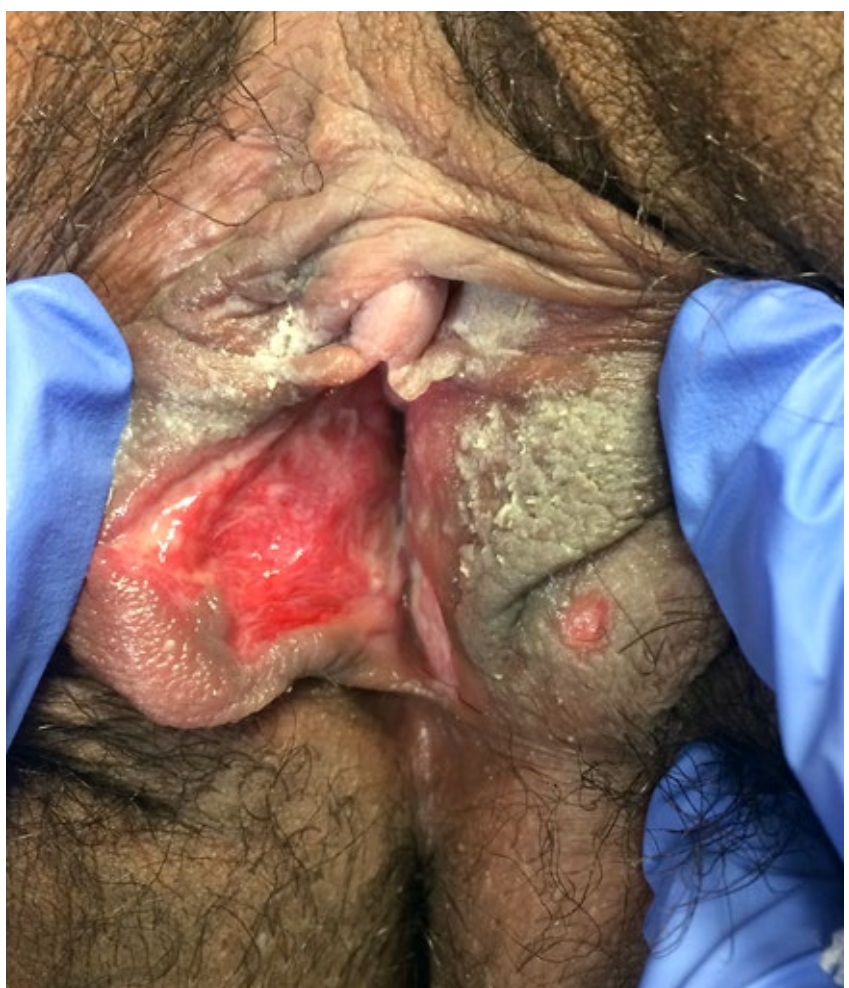

Figure 2 - Ulcerations after 5 days of symptomatic treatment.

\section{DIAGNOSIS}

\section{LIPSCHÜTZ ULCER}

Lipschütz ulcer or ulcus vulvae acutum is an uncommon and probably underdiagnosed entity characterized by an acute, painful vulvar ulceration of non-venereal origin. ${ }^{1-6}$ It is considered to be more common in adolescents or young women, who frequently are virgins, but several cases have also been reported in children. ${ }^{1-6}$ The etiology remains unknown. In recent years these ulcers have been related to infectious agents, including Epstein-Barr virus (EBV), Mycoplasma pneumoniae, Cytomegalovirus and influenza A. ${ }^{1-6}$ However, the mechanisms that lead to the formation of ulcers distant to the site of primary infection are poorly understood. ' Lipschütz ulcer presents as a sudden onset of painful vulvar ulcers, single or multiple, with raised, sharply demarcated borders and a necrotic and/or fibrinous center covered by grey exsudate or grey-black eschar. ${ }^{2,4}$ Secondary erythema and edema may be impressive. ${ }^{4}$ Typically, ulcers occur on the medial aspects of the labia minora, but they are also found on the labia majora, perineum and in the lower vagina. ${ }^{4}$ Bilateral "kissing lesions" (a mirrorlike vulvar distribution) are characteristic. ${ }^{2,4,6}$ Systemic symptoms such as fever, myalgias, headache, diarrhea, oral aphthae, enlarged lymph nodes or respiratory symptoms may be present. ${ }^{1}$
The diagnosis of Lipschütz ulcer is made by exclusion, after ruling out sexually transmitted infections, Behçet syndrome, extra-genital Crohn's disease, trauma or any other specific diagnosis. ${ }^{1-6}$ Initial workup may include complete blood cell count, bacterial culture, serologic test for syphilis, EBV, HIV, PCR assays for HSV. ${ }^{4,5}$ Sometimes skin biopsy from an ulcer edge can be necessary to rule out other conditions, but histologic examination is not of diagnostic value because findings are nonspecific. ${ }^{4,5}$ Treatment is mainly symptomatic, as the ulcers resolve spontaneously in a few weeks. ${ }^{1-6}$ Empiric treatment includes sitz baths, topical anesthetic and corticosteroids and oral analgesics. 4,6 Oral antibiotics and corticosteroids can be used for selected cases. ${ }^{4,5}$ These ulcers can be a great cause of anxiety for patients and their parents (when in children) and thus it is important to explain the benign nature of this condition. This case illustrates a rare cause of genital ulceration and the importance of its recognition in order to avoid unnecessary treatments.

Prémios / Apresentações: Caso clínico apresentado no Curso de Patologia Genital Feminina, organizado pelo GEIDST, decorrido a 14 de Abril de 2018 em Lisboa.

Awards / Presentations: Case report presented at the Course on Female Genital Pathology, organized by GEIDST, held on April 14, 2018 in Lisbon.

Conflitos de interesse: Os autores declaram não possuir conflitos de interesse.

Suporte financeiro: $O$ presente trabalho não foi suportado por nenhum subsídio ou bolsa.

Confidencialidade dos dados: Os autores declaram ter seguido os protocolos do seu centro de trabalho acerca da publicação dos dados de doentes.

Direito à privacidade e consentimento escrito: Os autores declaram que pediram consentimento para usar as imagens no artigo.

Conflicts of interest: The authors have no conflicts of interest to declare.

Financing Support: This work has not received any contribution, grant or scholarship.

Confidentiality of data: The authors declare that they have followed the protocols of their work center on the publication of data from patients.

Privacy policy and informed consent: The authors declare that have the written informed consent for the use of patient's photos in this article.

Proveniência e revisão por pares: Não comissionado; revisão externa por pares

Provenance and peer review: Not commissioned; externally peer reviewed 


\section{Qual o Seu Diagnóstico?}

\section{REFERENCES}

1. Vieira-Baptista P, Lima-Silva J, Beires J, Martinez-de- Oliveira J. Lipschütz ulcers: should we rethink this? An analysis of 33 cases. Eur J Obstet Gynecol Reprod Biol. 2016 198:149-52. doi: 10.1016/j.ejogrb.2015.07.016.

2. Mourinha V, Costa S, Urzal C, Guerreiro F. Lipschütz ulcers: uncommon diagnosis of vulvar ulcerations. BMJ Case Rep. 2016. pii: bcr2015214338. doi: 10.1136/ bcr-2015-214338.

3. Kinyó Á, Nagy N, Oláh J, Kemény L, Bata-Csörgö Z. Ulcus vulvae acutum Lipschütz in two young female patients. Eur J Dermatol. 201424:361-4. doi: 10.1684/ ejd.2014.2311.

4. Delgado-García S, Palacios-Marqués A, Martínez-Escoriza JC, Martín-Bayón TA. Acute genital ulcers. BMJ Case Rep. 2014. pii: bcr2013202504. doi: 10.1136/ bcr-2013-202504.

5. Brinca A, Canelas MM, Carvalho MJ, Vieira R, Figueiredo A. Lipschütz ulcer (ulcus vulvae acutum): a rare cause of genital lesion. An Bras Dermatol. 2012;87:622-4.

6. García JG, Pavón BM, Martín LM, Martínez BF, Norniella CM, Caro FÁ. Lipschütz ulcer: A cause of misdiagnosis when suspecting child abuse. Am J Emerg Med. 2016;34:1326.e1-2. doi: 10.1016/i.ajem.2015.12.027. 